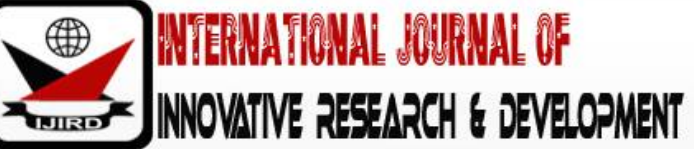

ISSN 2278 - 0211 (Online)

\section{Integrated Science Teachers' Pedagogical Content Knowledge}

\author{
Robert Kwadwo Siemoh \\ Tutor, Department of Science, Atebubu College of Education, Atebubu \\ Prince Duku \\ Tutor, Department of Science, Atebubu College of Education, Atebubu \\ Sampson Boye \\ Tutor, Department of Science, Atebubu College of Education, Atebubu
}

\begin{abstract}
:
This study was designed to investigate the Pedagogical Content Knowledge of Integrated Science teachers. The explanatory sequential mixed method design was used in this study. This is due to the fact that the study was of quantitative priority where greater emphasis was placed on the quantitative method while the qualitative method played a secondary role. The research was carried out in four circuits and eight Junior High School selected at random from these circuits in the AtebubuAmantin Municipality. The sample comprised fifteen (15) Integrated Science teachers. The instruments used were questionnaire and observation schedule. Cronbach alpha $(\alpha)$ value questionnaire was found to be 0.72 . The results showed that the Integrated Science teachers lacked consistency among the components of Pedagogical Content Knowledge (that is, knowledge of Integrated Science Curriculum, knowledge of students understanding of Integrated Science, knowledge about instructional strategies for teaching Integrated Science and knowledge about assessment in Integrated Science) discussed in this study. It was recommended that In-service trainings and courses be organised regularly for the Integrated Science Teachers at the Junior High School in the Atebubu-Amantin Municipality on ways of improving their Pedagogical Content Knowledge.
\end{abstract}

Keywords: Pedagogical content knowledge, integrated science, teachers

\section{Introduction}

The acquisition of general scientific literacy by every Ghanaian citizen is a requirement for successful living in modern times. Scientific culture develops and this aligns with the country's strategic programme of achieving scientific and technological literacy in the shortest possible time. This scientific culture is the antithesis to superstition and a catalyst for faster development (Curriculum Research Development Division, CRDD, 2012). It is traditionally accepted that for any effective teaching, the teacher should have both the content knowledge and the pedagogy.

According to Pihie and Sipon (2013), teachers' knowledge about the subject matter to be learned or taught and that of content to be covered in the syllabus as well the strategies to use to teach the subject are very important and when applied well will promote effective teaching and learning. One of the responsibilities of the Integrated Science teachers is to assist students to understand content of the subject. It is in the light of this Shulman $(1986 ; 1987)$ put forward that teachers make use of pedagogical content knowledge (PCK), a special kind of knowledge that teachers have about how to teach particular content to particular students in ways that promote understanding.

Teachers are generally considered to be the most essential elements in student learning and for that matter teachers' PCK, whether pre-service or in-service, is one of the most essential factors that affect the learning process (Karışan, Şenay \& Ubuz, 2013).Therefore, learning is not accomplished through teacher's approach to teaching and learning but rather how the teacher will integrate curriculum content to teacher's own professional content knowledge to diverse interests and abilities of learners. The teacher is required to blend both the nature and the scope of the subject to achieve its purpose, goals and objectives.

\section{Literature Review}

\subsection{Pedagogical Content Knowledge (PCK)}

Teaching is a multifaceted cognitive skill going on in an ill-structured, dynamic environment (Coulson, Feltovich, Jacobson \& Spiro (1991), as cited in Kereluik, Koehler \& Mishra, 2010). Expertise in teaching is dependent on flexible access to highly organized systems of knowledge (Borko \& Putnam, 2000). Teachers are expected to possess certain knowledge bases to be effective in their work. PCK is important in teacher education; it is a knowledge base for teaching (Van Driel, Verloop \& de Vos, 1998). These initially included, Content knowledge, Pedagogical knowledge, knowledge of 
curriculum, knowledge of learners, and knowledge of assessment. In 1987, Shulman introduced the idea of Pedagogical Content Knowledge as essential for teacher professionalism. He further argued that possessing knowledge of subject matter and teaching strategies was not enough for capturing the knowledge of good teachers. To illustrate the complicated ways in which teachers think about how particular content should be taught he put forward PCK as the content knowledge that emphasizes the teaching process, as well as the "ways of representing and formulating the subject that make it comprehensible to learners" (p. 9).

\subsection{Conceptualisation of PCK}

PCK has been conceptualised in diverse ways by educational researchers. Gess-Newsome and Lederman, (1999) called PCK an amalgamation or transformation, but not integration, of subject matter, pedagogical and context knowledge. Context knowledge was used in reference to the school and students. According to Van Driel, Verloop and de Vos, (1998), PCK is a construct that is surrounded by the knowledge of the subject matter, general pedagogical knowledge, and contextual knowledge. Park and Oliver (2008) identified five components of PCK as knowledge of students' thinking about science, science curriculum, science-specific instructional strategies, assessment of students' science learning and orientations of teaching science. Beyer and Davis (2012) viewed these components imperative because they work together to help teachers represent specific subject matter in ways that make it comprehensible to students. Boskurt and Kaya (2008) viewed PCK as the knowledge base required for teaching and comprising subject matter knowledge and pedagogical knowledge. They expanded these to show three main components, that is, knowledge of the curriculum, knowledge of learning difficulties of students and knowledge of instructional strategies and activities.

Mishra and Koehler (2006) posited that there are obviously several knowledge systems that are essential to teaching, as well as knowledge of student thinking and learning, and knowledge of subject matter. They identified knowledge of student thinking and learning of Integrated Science, and knowledge of Integrated Science subject matter as components of PCK.

Grossmann (1990) identified four distinct components of PCK: knowledge and beliefs for teaching subject matter; knowledge of students' understanding, conceptions and misconceptions of particular topics in a discipline; knowledge of the curriculum; and knowledge of instructional strategies and representations.

According to Carlsen (1999), PCK is a form of teacher knowledge and it includes five general knowledge domains: general education context, specific education context, general pedagogical knowledge, subject matter knowledge. It follows therefore that to attain an understanding of Integrated Science and the development of scientific knowledge while taking into consideration the needs of diverse groups of learners, teachers will have to display differentiated and integrated knowledge domains to effectively design and guide learning experiences. This implies that for Integrated Science teachers to be able to teach effectively, they need to have a deep PCK about Integrated Science which will enable them to coordinate all the aspects that influence instruction for effective learning to take place and enhance students' achievement. Teachers need to know how the various disciplines which constitute Integrated Science are interconnected. This knowledge provides a foundation for PCK that enables teachers to make concepts available to students.

Magnusson, Krajcik and Borko (1999) provided five components of the PCK of the science teacher as follows: Orientations toward science teaching, Knowledge about science curriculum, Knowledge about student understanding of science, Knowledge about assessment in science, and Knowledge about instructional strategies for teaching science. For the purpose of this study the researcher adapted four of them for measuring teachers' PCK in Integrated Science as follows:

- Knowledge about Integrated Science curriculum,

- Knowledge about student understanding of Integrated Science,

- Knowledge about assessment in Integrated Science, and

- Knowledge about instructional strategies for teaching Integrated Science.

\subsection{The Place of PCK in Science Education}

According to Appleton (2006) it is important to understand how science teachers organize and conceptualize their teaching in order to enhance student understanding of the concepts being taught. PCK has been an essential issue for science education researchers for some years now (Dana \& Friedrichsen, 2005). Berry, Loughran and Mulhall (2012) explained that effective science teaching is more likely if the teacher is not only knowledgeable about common student alternative conceptions/ misconceptions, but draws on this knowledge to shape teaching. In so doing, effective teachers monitor students' understanding in ways that allow them to be responsive to students' learning and create opportunities that help them to more fully grasp the concepts under consideration. Apparently, this cannot be realized by just telling students what they should think and why. Discovering ways of influencing the understandings that they construct and challenging students' alternative conceptions is at the heart of effective teaching. Therefore, as opposed to telling, it is crucial that teachers create meaningful and engaging activities, practices and discussion between students and/or between teacher and student(s) about science ideas and the ways these differ from everyday understandings (Berry, Loughran \& Mulhall, 2012). PCK is the knowledge base that enables science teachers to do these effectively. For some years now a significant number of researches has emphasized the impact of PCK on science teaching and learning, e.g. Abell, Rogers, Hanuscin, Lee and Gagnon, 2009 (as cited in Karışan, Şenay, \& Ubuz, 2013).

\subsection{Measuring PCK}

Literature indicates that researchers in various disciplines such as Science, English and Mathematics have used different tools to assess teachers' PCK. These methodologies and techniques range from the use of questionnaires (e.g. PCK Reflection Instrument), classroom observation schedules (Eshun, 2014; Geil, Briggs, Harlow \& Otero, 2006), Interview, 
document examination (e.g. end of term examination questions) (Mensah, 2013), multiple-test items, scenarios, concept maps (Budak \& Koseoglu, 2008). Others have used oral and written interviews and classroom observations. For example, Ball, Hill, Rowan and Schilling (2004) developed scenarios, for measuring mathematics, science and language teachers' content knowledge in a survey for the Study of Instructional Improvement (SII) Project. Each of the multiple-choice questions contained one correct answer and a number of incorrect answers. Open-ended questionnaires, Classroom observations, closed-ended questionnaire were used in combination with interview by Mochon and Neyera (2009) to measure different aspects of Mathematical Knowledge for Teaching (MKT). Piburn and Sawada (2000) developed and used Reformed Teaching Observation Schedule (RTOP) to measure "reformed" teaching which considered lesson design implementation, content and classroom culture. Mulhall, Berry and Loughran (2003) developed and used the Content Representation (CoRe), an interview of a particular content taught when teaching a topic, and Pedagogical and Professional-experience Repertoires (PaP-eRs) which is an account of practice intended to illuminate aspects of the CoRe in a particular classroom context. Other researchers had adapted and adopted some of these instruments and used them to suit the purposes of their research.

It is clear from literature that the measurement of PCK by researchers depends a lot on how each individual or group of researchers conceptualises PCK and that diverse instruments are available for adaption or adoption for its measurement.

\section{Methodology}

The explanatory sequential mixed method design was used. This is due to the fact that the study was of quantitative priority where greater emphasis was placed on the quantitative method while the qualitative method played a secondary role. Quantitative data was first collected using questionnaire and based on the information gathered from the quantitative data a qualitative data was later collected through classroom observation. The population for this study was all professionally trained Integrated Science teachers in the Atebubu-Amantin Municipality. The sample size for the study was fifteen (15) professionally trained Integrated Science teachers. Simple random sampling technique was employed by the researchers to select the sample of circuits, schools and teachers for the study. The researchers also used simple random sampling technique to select ten (10) of the teachers out of the fifteen (15) teachers for classroom observation. Questionnaires and Observation were used as instruments in gathering data for the study. To enhance the validity of this study, the researchers face-validated the instruments by discussing the questionnaires and the PCK observation guide adapted from Park and Oliver (2008) with some of the tutors in the Science Department of Atebubu College of Education. The Cronbach alpha $(\alpha)$ value for the questionnaire was found to be 0.72 to ascertain its reliability. To further enhance the validity of the study, the researchers used both qualitative and quantitative approaches to collect the data. The reason they used diverse sources was because they wanted to draw their findings based on a rich source of data. Data collection was done through the administration of questionnaire and classroom observation of teachers in selected schools. The quantitative data entry and analysis was done by using the IBM Statistical Package for Social Sciences (SPSS) software version 22. Descriptive statistics (means, standard deviation and frequencies) and percentages were used to analyse the respondents' responses to the questionnaire after they had been coded. The analysed data were presented in tables as means and percentages.

\section{Data Analysis and Interpretation}

The question was answered under these four PCK components: Knowledge of Integrated Science Curriculum (KIC), Knowledge of Students Understanding of Integrated Science (KSU), Knowledge about Instructional Strategies for Teaching Integrated Science (KIS) and Knowledge about Assessment in Integrated Science (KAI)

\subsection{Knowledge of Integrated Science Curriculum (KIC)}

\begin{tabular}{|c|c|c|c|c|}
\hline Item & Statements & N & Mean & Std. Deviation \\
\hline 2 & $\begin{array}{c}\text { Integrated Science is concerned about curiosity, creativity in } \\
\text { solving problems and critical thinking. }\end{array}$ & 15 & 4.13 & 0.990 \\
\hline 9 & $\begin{array}{c}\text { The Integrated Science curriculum is based on the Spiral } \\
\text { Approach. }\end{array}$ & 15 & 3.20 & 1.082 \\
\hline 13 & $\begin{array}{c}\text { Integrated Science does not recognise the vulnerability of the } \\
\text { natural environment. }\end{array}$ & 15 & 2.93 & 0.961 \\
\hline 15 & $\begin{array}{c}\text { Integrated Science is not necessarily the holistic study of the } \\
\text { science disciplines. }\end{array}$ & 15 & 2.53 & 1.060 \\
\hline
\end{tabular}

Table 1: Teachers' Knowledge of Integrated Science Curriculum (Questionnaire)

Field Data: 2018

Results in Table 1 show that the Integrated Science Teachers sampled for the study agreed that Integrated Science is concerned about curiosity, creativity in solving problems and critical thinking $(\mathrm{M}=4.13, \mathrm{SD}=0.990)$. The teachers also respectively agreed that Integrated Science recognises the vulnerability of the natural environment and also that Integrated Science is the holistic study of the various science disciplines $(\mathrm{M}=2.93, \mathrm{SD}=0.961)$ and $(\mathrm{M}=2.53, \mathrm{SD}=1.060)$. On the other hand, the teachers were somehow neutral to the Integrated Science curriculum is based on the Spiral Approach $(\mathrm{M}=3.20, \mathrm{SD}=1.082)$. 


\begin{tabular}{|c|c|c|c|c|c|}
\hline PCK Component & Statements & \multicolumn{3}{c|}{ Levels } \\
\cline { 3 - 6 } $\begin{array}{c}\text { Knowledge of } \\
\text { Integrated Science } \\
\text { Curriculum }\end{array}$ & $\begin{array}{c}\text { Attempt to encourage creativity and critical thinking } \\
\text { through activities and questioning. }\end{array}$ & 1 & 3 & 6 & - \\
\cline { 2 - 6 } & $\begin{array}{c}\text { Attempt to integrate concepts to make the subject } \\
\text { holistic to students. }\end{array}$ & 2 & 1 & 3 & 4 \\
\cline { 2 - 6 } & $\begin{array}{c}\text { Understanding of the application of concepts in } \\
\text { everyday life. }\end{array}$ & 4 & 3 & 3 & - \\
\cline { 2 - 6 } & Understanding of the curriculum as spiral. & 7 & 2 & 1 & - \\
\hline
\end{tabular}

Table 2: Teachers Knowledge of Integrated Science Curriculum (Observation)

Where L=Limited Knowledge, B=Basic Knowledge, P=Proficient Knowledge, E=Exemplary Knowledge.

Field Data: 2018

The results in Table 2 show that out of the ten (10) teachers observed, 1(10\%), 3(30\%), 6(60\%) of them showed limited, basic and proficient knowledge in attempting to encourage creativity and critical thinking through activities and questioning. Also, 2(20\%), 1(10\%), 3(30\%), 4(40\%) showed limited, basic, proficient and exemplary knowledge in attempting to integrate concepts to make the subject holistic to students respectively. Again, $4(40 \%)$ had limited, 3(30\%) had basic and 3(30\%) had proficient knowledge in understanding the application of Integrated Science concepts in everyday life. Furthermore, 7(70\%), 2(20\%) and 1(10\%) showed limited, basic and proficient knowledge in understanding the Integrated Science curriculum as spiral.

\subsection{Knowledge of Students' Understanding of Integrated Science (KSU)}

\begin{tabular}{|c|c|c|c|c|}
\hline Item & Statements & $\mathbf{N}$ & Mean & Std. Deviation \\
\hline 1 & $\begin{array}{c}\text { It is not necessary for the teacher to be aware of the topics } \\
\text { difficult for students in Integrated Science. }\end{array}$ & 15 & 3.33 & 1.759 \\
\hline 7 & $\begin{array}{c}\text { Students' misconceptions should be overlooked by teachers to } \\
\text { enable systematic presentation of a lesson. }\end{array}$ & 15 & 3.93 & 1.280 \\
\hline 12 & $\begin{array}{c}\text { Teacher knowing students' prior knowledge and connecting it } \\
\text { to new knowledge is an effective way of teaching. }\end{array}$ & 15 & 4.07 & 0.961 \\
\hline 16 & $\begin{array}{c}\text { Teacher should pose questions to correct students' } \\
\text { misconceptions. }\end{array}$ & 15 & 4.33 & 0.488 \\
\hline
\end{tabular}

Table 3: Teachers Knowledge of Students Understanding of Integrated Science (KSU)

Field Data: 2018

The results in Table 3 show that the teachers agreed that teacher knowing students' prior knowledge and connecting it to new knowledge is an effective way of teaching $(\mathrm{M}=4.07, \mathrm{SD}=0.961)$ and that teacher should pose questions to correct students' misconceptions ( $\mathrm{M}=4.33, \mathrm{SD}=0.488$ ). In contrast, the teachers disagreed that Students' misconceptions should be overlooked by teachers to enable systematic presentation of a lesson $(\mathrm{M}=3.93, \mathrm{SD}=1.280)$. The teachers agreed that it is not necessary for the teacher to be aware of the topics difficult for students in Integrated Science ( $M=3.33$, $\mathrm{SD}=1.759)$.

\begin{tabular}{|c|c|c|c|c|c|}
\hline PCK Component & Statements & \multicolumn{3}{|c|}{ Levels } \\
\cline { 3 - 6 } & & $\mathrm{L}(1)$ & $\mathrm{B}(2)$ & $\mathrm{P}(3)$ & $\mathrm{E}(4)$ \\
\hline Knowledge of Students & & 6 & 3 & 1 & - \\
\cline { 2 - 6 } Understanding of \\
\cline { 2 - 6 } & Overlooking students' misconceptions. & 3 & 5 & 2 & - \\
\cline { 2 - 6 } & $\begin{array}{c}\text { Understanding of students' common } \\
\text { learning difficulties. }\end{array}$ & 2 & - & 5 & 3 \\
\cline { 2 - 6 } & $\begin{array}{c}\text { Knowing students' prior knowledge and } \\
\text { connecting it to new knowledge. }\end{array}$ & 4 & 4 & 1 & 1 \\
\cline { 2 - 6 } & $\begin{array}{c}\text { Posing questions to correct students' } \\
\text { misconceptions. }\end{array}$ & & & & \\
\cline { 2 - 6 }
\end{tabular}

Table 4: Teachers Knowledge of Students Understanding of Integrated Science ( observation)

Field data: 2018

The results in table 2(b) show that out of the ten (10) teachers observed, $5(50 \%), 3(30 \%), 2(20 \%)$ of them had exemplary, proficient and limited knowledge respectively in students' prior knowledge and connecting it to new knowledge. Also, 4(40\%), 3(30\%), 2(10\%) and 1(10\%) respectively showed limited, basic, proficient and exemplary knowledge in posing questions to correct students' misconceptions. Again, 6(60\%) had limited, 3(30\%) had basic and $1(10 \%)$ had proficient knowledge in overlooking students' misconceptions. 
4.3. Teachers Knowledge about Instructional Strategies for Teaching Integrated Science (KIS)

\begin{tabular}{|c|c|c|c|c|}
\hline Item & Statements & $\mathbf{N}$ & Mean & Std. Deviation \\
\hline 4 & $\begin{array}{c}\text { I use different ways/ methods to develop students } \\
\text { understanding of Integrated Science. }\end{array}$ & 15 & 4.20 & 1.207 \\
\hline 6 & $\begin{array}{c}\text { Teacher adapting to variations in ability and background of } \\
\text { students' does not affect the lesson. }\end{array}$ & 15 & 2.47 & 1.356 \\
\hline 10 & Involving students in the lesson fully delays the lesson. & 15 & 4.13 & 0.990 \\
\hline 14 & $\begin{array}{c}\text { The teacher should teach most of the time using the student } \\
\text { centred-method. }\end{array}$ & 15 & 3.27 & 1.335 \\
\hline
\end{tabular}

Table 5: Teachers Knowledge about Instructional Strategies for Teaching

Integrated Science (Questionnaire)

Field Data: 2018

The result in Table 5 indicates that the teachers use different ways/methods to develop students' understanding of Integrated Science $(\mathrm{M}=4.2, \mathrm{SD}=1.207)$. The teachers agreed that teacher adapting to variations in ability and background of students affect the lesson $(\mathrm{M}=2.47, \mathrm{SD}=1.356)$. Also, the teachers agreed with the statement that involving students in the lesson fully delays the lesson $(\mathrm{M}=4.13, \mathrm{SD}=0.990)$. On the other hand, the teachers were somehow neutral to the statement that the teacher should teach most of the time using the student-centred method $(\mathrm{M}=3.27, \mathrm{SD}=1.335)$.

\begin{tabular}{|c|c|c|c|c|c|}
\hline PCK Component & Statements & \multicolumn{3}{|c|}{ Levels } \\
\cline { 3 - 6 } & & $\mathrm{L}(1)$ & $\mathrm{B}(2)$ & $\mathrm{P}(3)$ & $\mathrm{E}(4)$ \\
\hline $\begin{array}{c}\text { Knowledge of } \\
\text { Instructional } \\
\text { Strategies (KIS) }\end{array}$ & Use different methods to develop students understanding of & - & 2 & 3 & 5 \\
& Integrated Science. & & & & \\
\cline { 2 - 6 } & Adapting to variations in ability and background of students. & 7 & 2 & 1 & - \\
\cline { 2 - 6 } & Involving students in the lesson. & 4 & 5 & 1 & - \\
\hline
\end{tabular}

Table 6: Teachers Knowledge about Instructional Strategies for

Teaching Integrated Science (Observation)

Field Data: 2018

The results in Table 6 show that 5(50\%), 3(30\%), 2(20\%) of the teachers had exemplary, proficient, and basic knowledge respectively in the use of different methods to develop students understanding of Integrated Science. Also, $7(70 \%), 2(20 \%), 1(10 \%)$ of the teacher observed showed limited, basic and proficient knowledge respectively in adapting to variations in ability and background of students. Again, 4(40\%) showed limited, 5(50\%) showed basic and 1(10\%) showed proficient knowledge in involving students in the lesson.

\subsection{Teachers Knowledge about Assessment in Integrated Science (KAI)}

\begin{tabular}{|c|c|c|c|c|}
\hline Item & Statements & $\mathbf{N}$ & Mean & Std. Deviation \\
\hline 3 & $\begin{array}{c}\text { Summative assessment is the only way to test students } \\
\text { understanding of Integrated Science. }\end{array}$ & 15 & 2.40 & 1.056 \\
\hline 5 & $\begin{array}{c}\text { The teacher has to ask students questions for proper understanding } \\
\text { in the classroom. }\end{array}$ & 15 & 3.93 & 0.961 \\
\hline 8 & $\begin{array}{c}\text { Teacher providing hands-on activities for students to learn } \\
\text { Integrated Science wastes time. }\end{array}$ & 15 & 4.20 & 0.775 \\
\hline 11 & $\begin{array}{c}\text { The teacher should give all students in the classroom a chance to } \\
\text { answer questions. }\end{array}$ & 15 & 2.67 & 1.633 \\
\hline
\end{tabular}

Table 7: Teachers Knowledge about Assessment in Integrated Science (Questionnaire)

Field Data: 2018

The result in Table 7 show that the teachers disagreed with the statement that summative assessment is the only way to test students' understanding of Integrated Science ( $\mathrm{M}=2.40, \mathrm{SD}=1.056)$. Also, the teachers' agreed that the teacher has to ask students questions for proper understanding in the classroom $(\mathrm{M}=3.93, \mathrm{SD}=0.961)$. The teachers agreed that teacher providing hands-on activities for students to learn Integrated Science waste time ( $M=4.20, S D=0.775)$. Again, the teachers disagreed with the statement that the teacher should give all students in the classroom a chance to answer questions $(\mathrm{M}=2.67, \mathrm{SD}=1.633)$.

\begin{tabular}{|c|c|c|c|c|c|}
\hline PCK Component & Statements & \multicolumn{3}{|c|}{ Levels } \\
\cline { 3 - 6 } Knowledge of \\
\cline { 2 - 6 } Assessment & Questions to probe student understanding. & 3 & 3 & 4 & - \\
\cline { 2 - 6 } & Provides hands-on activities for students. & 6 & 4 & 1 & - \\
\cline { 2 - 6 } & Gives all students in the classroom chance to answer questions. & 4 & 4 & 1 & 1 \\
\cline { 2 - 6 } & &
\end{tabular}

Table 8: Teachers Knowledge about Assessment in Integrated Science (Observation)

Field Data: 2018 
The results in Table 8 show that out of the ten (10) teachers observed, 3(30\%) showed limited, 3(30\%) showed basic, $4(40 \%)$ of them showed proficient knowledge in asking questions to probe students' understanding in the classroom. Also, 6(60\%), 4(40\%), 1(10\%) showed limited, basic, proficient knowledge respectively in providing hands-on activities for the students to learn Integrated Science. Again, 4(40\%) showed limited, 4(40\%) showed basic, 1(10\%) showed proficient and $1(10 \%)$ showed exemplary knowledge in giving all students in the classroom the chance to answer questions.

\section{Key Findings}

The analysis of the data revealed the following findings:

- Even though the Integrated Science teachers in the Atebubu-Amantin Municipality used in the study were familiar with the curriculum, they lacked knowledge of a major aspect of the curriculum, which is its spiral nature.

- Even though the Integrated Science teachers showed knowledge of students' prior knowledge and connected it to new knowledge, they were of the view that students' misconceptions be overlooked to enable systematic presentation of lessons.

- The teachers were also of the view that it is not necessary for teachers to be aware of topics difficult to students in Integrated Science. This indicates that the teachers lacked knowledge of students' understanding of Integrated Science.

- The teachers were in a dilemma as to whether the student-centred approach to teaching is effective or the teacher-centred approach.

- Although the teachers were aware that summative assessment was not the only means of testing students understanding, they did not have enough knowledge about assessment methods in Integrated Science as they rarely asked students' questions to probe their understanding.

\section{Discussion}

The results on teachers' knowledge of Integrated Science curriculum (syllabus) showed that the teachers were familiar with the Integrated Science curriculum (syllabus) they used in teaching the students. Notwithstanding the fact that the teachers were familiar with the curriculum, they lacked knowledge of a major aspect of the curriculum, which is its spiral nature. According to Ball, Hill \& Schilling (2004), knowledge of curriculum involves awareness of how topics are arranged both within a school year and over time and ways of using curriculum resources, such as textbooks, to organise a program of study for students. Their responses to the question and the observation checklist on this aspect showed that seven (7) out of the ten (10) teachers had limited level of this component of PCK. The spiral nature of the curriculum is characterized by revisiting concepts and skills at different levels with increasing degrees of depth at each stage. According to CRDD (2012), the spiral nature of the Integrated Science curriculum has the benefit of matching scientific concepts and skills to students' cognitive development and therefore helps students to build a gradual mastery of scientific skills. This means the teachers' inability to portray the spiral nature of the curriculum in the classroom (e.g. they did not link the development of the concepts being taught with what the students had already been taught in previous years on the same topic). This is also an indication that they do not know that they had to match scientific concepts and skills to students' cognitive development. Lack of such knowledge and prior preparation to carefully match science concepts and skills to students' cognitive development will surely result in students having difficulty in understanding what they are taught. This will in turn lead to poor academic performance. It also shows a loophole in the Integrated Science teachers' PCK in the area of the Integrated Science curriculum (syllabus) as well.

Also, results on teachers' knowledge of students understanding of Integrated Science show that majority of the teachers agreed that it is important for teachers to know students' prior knowledge and connect it to new knowledge. This finding is confirmed by Svinicki (1994) who said it is helpful to know what knowledge students bring to the learning setting as this enables teachers to guide students unlearn their misconceptions which may interfere with the new knowledge (concept) to be learnt. According to Svinicki, "an incorrect bit of prior knowledge which is not corrected could keep the students from understanding an entire lecture [lesson]" (p. 2). Even though the teachers' showed knowledge of students' prior knowledge and connecting it to new knowledge, they were of the view that students' misconceptions be overlooked to enable systematic presentation of lessons. They were also of the view that it is not necessary for teachers to be aware of topics difficult to students in Integrated Science. From these it can be concluded that the teachers lacked knowledge of students understanding of Integrated Science. As Kim (2004) posited that knowledge of students' understanding comprises students' common errors and misconceptions, learning difficulties and confusions and their prior knowledge. These components with other factors work together to bring effective lesson presentation which leads to students' achievement. Therefore, absence of any of these aspects alludes to lack of knowledge of students' understanding. Again, the results on teachers' knowledge of instructional strategies for teaching Integrated Science indicate that the teachers agreed that using different ways/ methods to develop students understanding in Integrated Science is crucial. In spite of this, they held the idea that when they adapted to variations in ability and background of students and also involved students in lessons, the lesson will be delayed. The teachers were in a dilemma as to whether the student-centred approach to teaching is effective or the teacher-centred approach. This means that there is a gap regarding the teachers' knowledge about instructional strategies for teaching Integrated Science. This assertion is supported by the findings of Halim and Meerah (2002) about Malaysian Trainee Integrated Science teachers that the teachers were unable to employ the appropriate teaching strategies required explaining scientific ideas.

Furthermore, the results on teachers' knowledge of assessment in Integrated Science showed that even though the teachers were aware that summative assessment is not the only means of testing students' understanding of Integrated 
Science, they did not have enough knowledge about assessment methods in Integrated Science. Formative assessment was virtually absent in their teaching. They rarely asked the students questions to probe their understanding. They also provided no hands-on activities for students. Again, only on a few occasions were all students allowed to participate in lessons fully through contributions. Most of the teachers focused on contributions from a few brilliant students. This goes a long way to confirm the teachers' disagreement on adapting to variations in ability and background of students. Abell (2007), revealed that Science teachers lack crucial PCK including knowledge of assessment. This means that most Science teachers lack knowledge of assessment methods.

In a nutshell, the Integrated Science teachers lacked consistency among the four components of PCK discussed above and this affect their ability to present concepts well to students' understanding. This is what Ball et al. (2004) described as the "inability of many teachers to hear student' flexibility, represent ideas in multiple ways, connect content to contexts effectively, and think about things in ways other than their own" (p.86). Also, PCK for effective teaching is the integration of all aspects of an Integrated Science teachers' knowledge in a highly complex way. Thus, lack of coherence among the components would be problematic within an individual's developing PCK and increased knowledge of a single component may not be sufficient to stimulate change in practice (Park \& Oliver, 2008).

\section{Conclusion}

It was concluded that the Integrated Science teachers in the Atebubu-Amantin Municipality used in the study lacked consistency among the levels of the components of the PCK (knowledge of Integrated Science Curriculum, knowledge of students understanding of Integrated Science, knowledge about instructional strategies for teaching Integrated Science and knowledge about assessment in Integrated Science) studied and this could affect their ability to present concepts well for students to comprehend. The lack of coherence among the components of PCK is challenging especially within an individual's developing PCK and therefore increased knowledge of a single component may not be enough to encourage change in practice (Park \& Oliver, 2008).

\section{Recommendations}

Based on the finding of the study the following recommendations are made:

- In-service trainings and courses should be organised regularly for JHS Integrated Science teachers in the AtebubuAmantin Municipality on ways of improving their PCK.

- The teachers need to be reminded of their key function which is to facilitate learning.

- There is the need to plan and conduct effective professional development initiatives, including pre- and in-service training, to transform the teachers' epistemologies in line with the current theories of teaching and learning.

- Ghana National Association of Science Teachers (GAST) should also organised orientations, seminars and workshops for newly trained teachers from the Universities and Colleges of Education who are posted to district on how to effectively teach the subject (Integrated Science).

- Universities and Colleges of Education should provide a broad chance to Integrated Science teachers to develop their PCK.

\section{References}

i. Abell, S. K. (2007). Research on science teacher knowledge. In S. K. Abell, \& I. S. G.Lederman (Ed.), Handbook of research on science education (pp. 1105-1151). New Jersey: Lawrence Erlbaum Associates.

ii. Appleton, K. (2006). Science pedagogical content knowledge and elementary school teachers. Elementary science teacher education: International perspectives on contemporary issues and practice, pp. 31-54.

iii. Ball, D. L., Hill, H. C., \& Schillings, S. G. (2004). Developing Measures of Teacher's Mathematics Knowledge for Teaching. Elementary School Journal, 105(1), pp. 11-30.

iv. Berry, A., Loughran, J., \& Mulhall, P. (2012). Understanding and Developing Science Teachers' Pedagogical Content Knowledge. Springer Science \& Business Media, (12).

v. Beyer, J. C \& Davis, A. E. (2012). Learning to Critique and Adapt Science Curriculum Materials: Examining the Development of Pre-service Elementary Teachers' Pedagogical Content Knowledge. Science Teacher Education, 96(1), pp. 130-157.

vi. Borko, H., \& Putnam, R. T. (2000). What do new views of knowledge and thinking have to say about research on teacher learning? Educational Researcher, 29(1), pp. 4-15.

vii. Boskurt, O., \& Kaya, O.N. (2008). Teaching about ozone layer in Turkey: Pedagogical content knowledge of science teachers. Public Understanding of Science, 17(2), pp. 261-276.

viii. Budak, E.L., \& Koseoglu, F. (2008). What concept map tell us about changes in PCK of prospective chemistry teachers participating in an inquiry based workshop? Proceedings of the Third International Conference on Concept Mapping. Tallinn, Estonia \& Helsinki, Finland.

ix. Carlsen, W. (1999). Domains of teacher knowledge. In Gess-Newsome, J., \& Lederman, N. G. (Eds.), Examining Pedagogical Content Knowledge: The Construct and its Implications for Science Education. Dordrecht: Kluwer Academic.

x. Curriculum Research Development Division (CRDD). (2012). National Syllabus for Integrated Science (Junior High School). Accra, Ghana: Author.

xi. Dana, T. M., \& Friedrichsen, P. M. . (2005). Substantive-level theory of highly regarded secondary biology teachers' science teaching orientations. Journal of Research in Science Teaching, 42, pp. 218-244. 
xii. Eshun, V. (2014). Science Teashers' Pedagogical Content Knowledge and Its Exhibition in Classroom Practice: A Case Study in Accra Metropolis. (Doctoral Thesis). University of Education, Winneba, Ghana.

xiii. Geil, K., Briggs, D., Harlow, D., \& Otero, V. (2006). Measuring sophisication of understanding of teaching and learning. "Issues in Teacher Preparation". Poster Session. San Francisco, AERA.

xiv. Gess-Newsome, J., \& Lederman, N. G. (1999). Examining Pedagogical content knowledge: The construct and its implications for science education. Boston, MA: Kluwer Academic Publishers.

xv. Grossman, P. L. (1990). The making of a teacher: Teacher knowledge and teacher education. New York: Teachers College Press.

xvi. Halim, L., \& Meerah, S.M.M. (2002). Science trainee teachers' pedagogical content knowledge and its influence on physics teaching. Research in Science \& Technological Education, 20(2), pp. 215-225.

xvii. Karışan, D., Şenay, A., \& Ubuz, B. (2013). A Science Teacher's PCK in Classes with Different Academic Success Levels. Journal of Educational and Instructional Studies in the World, p. 22.

xviii. Kereluik, K., Mishra, P., \& Koehler, M. (2010). Reconsidering the T and C in TPACK: Repurposing technologies for interdisciplinary knowledge. In Society for Information Technology \& Teacher Education International Conference, (Vol. 2010, No. 1, pp. 3892-3899).

xix. Kim, G. (2004). The Pedagogical Content Knowledge Of Two Middle-School. p.129.

xx. Magnusson, S., Krajcik, J., \& Borko, H. (1999). Nature, sources, and development of Pedagogical content knowledge for science teaching. In I. J.-N. N.G.Lederman (Ed.), Examining pedagogical content knowledge: The construct and its implications for science education (pp. 95-132). Dordrecht: Kluwer.

xxi. Mensah, M. F. (2013). Teachers' pedagogical Content Knowledge in Social Studies And Their Assessment Practices at the Senior High Schools in Sekondi-Takoradi Metropolis (Doctoral dissertation). University of Education, Winneba, Ghana.

xxii. Mishra, P., \& Koehler, M. (2006). Technological pedagogical content knowledge: A framework for teacher knowledge. The Teachers College Record, 108(6), pp. 1017-1054.

xxiii. Mochon, S., \& Neyra, S.A. (2009). Comparison of Instruments to Explore different aspects of MKT for Arithmetic: In S. L. Swars (Ed.), Proceedings of 31st annual meeting of the North American Chapter of International Group for the Psychology of Mathematics Education,. Atlanta: GA: Georgia State University.

xxiv. Mulhall, P., Berry, A., \& Laughran, J. (2003). Frameworks for representing science teachers' pedagogical content knowledge. Asia Pacific forum on science learning and teaching., 4(2).

xxv. Park, S. \& Oliver, J. S (2008). Revisiting the conceptualisation of pedagogical content knowledge (PCK): PCK as a conceptual tool to understand teachers as professionals. Research in Science Education, 38(3), pp. 261-284.

xxvi. Piburn, M., \& Sawada, D. (2000). Reformed Teaching Observation Protocol (RTOP): Reference Manual (ACEPT Technical Report No. IN00-3).

xxvii. Pihie, Z. A. L., \& Sipon, M. (2013). Implementing Pedagogical Content Knowledge in teaching and Learning Entrepreneurship at Community College: an Instructional Enrichment. Procidia Graduate Research in Education , pp. 532-539.

xxviii. Shulman, L. S. (1986). Those who understand: Knowledge growth in teaching. Educational Researcher, 15(2), pp. 4-14.

xxix. Shulman, L. S. (1987). Knowledge and teaching: Foundations of the new reform. Harvard Educational Review, 57(1), pp. 1-22.

xxx. Svinicki, M. (1994). What they don't know can hurt them: the role of prior knowledge in learning. Teaching excellence, 5(4), pp. 1-2.

xxxi. Van Driel, J. H., Verloop, N., \& De Vos, W. (1998). Developing science teachers' pedagogical content knowledge. Journal of Research in Science Teaching: The Official Journal of the National Association for Research in Science Teaching, 35(6), 673-695. 